\title{
RELIGIÃO, POLÍTICA E LUTA DE CLASSES: AS REFLEXÕES DE FRIEDRICH ENGELS SOBRE 0 FENÔMENO RELIGIOSO'
}

\author{
Wallace Cabral Ribeiro²
}

RESUMO: O objetivo desta pesquisa é identificar e analisar como Friedrich Engels trata sociologicamente a questão do fenômeno religioso e sua articulação orgânica com a política no contexto de luta de classes. Para alcançar este objetivo, nos deteremos sobre suas reflexões acerca dos conflitos sociorreligiosos protagonizados pelos camponeses na Alemanha entre 1524 e 1525. A principal obra analisada é As Guerras camponesas na Alemanha de 1850, na qual o autor procura compreender o significado da experiência religiosa a partir das "circunstâncias materiais existentes", levando em consideração suas múltiplas determinações, que envolvem aspectos históricos, estruturais, conjunturais, situacionais e espaciais em suas dimensões micro e macro sociais. Dois pesquisadores participaram desta pesquisa concedendo cada um deles uma entrevista, com o propósito de compreender a complexidade do sistema de pensamento de Engels, seus métodos, conceitos e categorias. São eles: Michael Löwy e Lívia Cotrim (in memoriam).

${ }^{1}$ Este artigo foi extraído do primeiro capítulo de minha dissertação de mestrado, sob a orientação da professora Christina Vital da Cunha e apresentado no Grupo de Trabalho "Religião, arte de política na cidade" no VIII Seminário Fluminense de Sociologia 2019.

2 Mestre pelo Programa de Pós-graduação em Sociologia da Universidade Federal Fluminense (PPGS - UFF), bacharel em Sociologia pela mesma instituição.
PALAVRAS-CHAVE: Circunstâncias materiais; materialismo histórico; conflitos sociorreligiosos; campo de força; representação religiosa.

\section{RELIGION, POLITICS AND CLASS STRUGGLE: FRIEDRICH ENGELS' REFLECTIONS ON THE RELIGIOUS PHENOMENON}

ABSTRACT: The aim of this research is to identify and analyze how Friedrich Engels deals sociologically with the issue of the religious phenomenon and its organic articulation with politics in the context of class struggle. To achieve this goal, we will dwell on his reflections on the socio-religious conflicts carried out by peasants in Germany between 1524 and 1525. The main work analyzed is The Peasant Wars in Germany of 1850, in which the author seeks to understand the meaning of religious experience from "existing material circumstances", taking into account its multiple determinations, which involve historical, structural, conjunctural, situational and spatial aspects in their micro and macro social dimensions. Two researchers participated in this research, granting each one an interview, with the purpose of understanding the complexity of Engels' thought system, its methods, concepts and categories. They are: Michael Löwy and Lívia Cotrim (in memoriam).

KEYWORDS: Material circumstances; historical materialism; socio-religious conflicts; force field; religious representation. 


\section{INTRODUÇÃO}

"o direito à revolução é o único 'direito histórico' real"

(ENGELS, 1895)

Friedrich Engels (1820-1895), ao longo de sua trajetória político intelectual, dedicou-se aos mais variados temas. Em sua vasta obra, é possível encontrar conhecimentos relacionados às áreas de história, antropologia, ciência política, economia, ciências da natureza, educação, relações de gênero, ciências jurídicas, filosofia, ciências militares, sociologia da religião, entre outros. A algumas dessas áreas, Engels se dedicou com mais afinco, por isso contribuiu de forma mais significativa, tanto do ponto de vista quantitativo quanto qualitativo.

Ao pesquisar sobre sua vida e obra, percebemos que Engels escreveu significativamente sobre o fenômeno religioso, contudo, suas reflexões nesse campo de conhecimento eram (são) timidamente estudadas ou mobilizadas. Para Elizete da Silva,

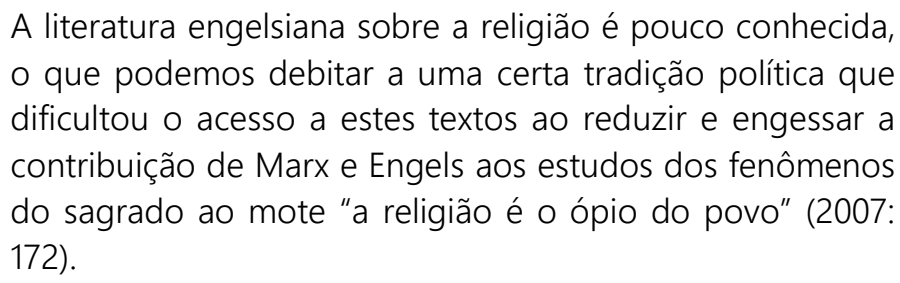

Para Michael Löwy (2015), Engels é mais do que um colaborador da sociologia da religião, mas um dos fundadores deste campo de conhecimento ${ }^{3}$. Isso decorreria do fato de que, ao analisar o conflito religioso que ocorreu entre católicos, luteranos e anabatistas ${ }^{4}$. No âmbito das reformas protestantes, Engels apontou a base material de desenvolvimento de cada uma dessas correntes religiosas e os elementos sociais que geraram a aproximação, por afinidade de sentido, de cada uma delas com uma determinada classe social (representação religiosa). Dessa forma, Engels indica que a religião é um fenômeno social historicamente construído e que se encontra imersa na luta de classes, uma vez que "cada classe social tem sua interpretação da religião, em função de sua posição social" (LÖWY, 2019, entrevista concedida a esta pesquisa).

3 Apesar Michael Löwy compreender Friedrich Engels como um sociólogo do fenômeno religioso, o próprio Engels nunca se identificou como tal.

4 Os anabatistas entendiam que ninguém deveria ser considerado automaticamente cristão, a fé cristã não poderia ser imposta, sua aceitação deve ser fruto de uma escolha livre $e$ consciente, portanto, somente os adultos estariam em condições adequadas de fazer essa escolha. É dessa interpretação teológica que os anabatistas se colocavam contra o batismo infantil. $\mathrm{O}$ batismo simbolizava adesão ao grupo e a nova fé, quem já houvesse sido batizado pela Igreja de Roma quando criança deveria realizá-lo novamente. Essa exigência originou o nome anabatismo, que deriva "do grego, Ana (re) e baptizo (batismo)" (NETO, 2016: 35) 
Desde a juventude, Engels reflete sobre a questão religiosa, como nas Cartas de Wuppertal, de 1839, e na tríade de ensaios sobre Schelling: Schelling em Hegel (1841), Schelling e a Revelação (1841/1842) e Schelling Filósofo Cristão (1842). Na maturidade, produziu uma tríade de textos com reflexões sociológicas sobre o cristianismo primitivo, a saber: Bruno Bauer e o Início do Cristianismo (1882), O livro da Revelação (1883) e Contribuição à história do cristianismo primitivo (1895). Estes textos influenciaram marxistas de outras gerações, como Karl Kautsky, Antônio Labriola e Rosa Luxemburgo. O estudo em tela se dedicará às reflexões de Engels produzidas em uma fase diferente das duas acima mencionadas (juventude e maturidade), a principal obra analisada será As Guerras Camponesas na Alemanha, publicada em 1850.

Neste livro, o pensador alemão compreende que os anabatistas, durante as reformas protestantes, não se apresentavam como uma religião aplacadora das dores deste mundo, que tendia para o conservadorismo ou reacionarismo. Tratava-se de uma experiência religiosa que contestava toda a ordem vigente e que propunha a edificação de uma sociedade igualitária, seu "programa exigia o estabelecimento imediato do reino de Deus da era milenar de felicidade" (ENGELS, 2010[1850]: 83). Os anabatistas eram mais do que contestadores da ordem social, eram revolucionários e a religião era seu substrato político.

Para Engels, a religião não é apenas o reflexo invertido da realidade socioeconômica, ela pode antecipar o futuro propondo mudanças na realidade, afetando as "circunstâncias materiais existentes". Em certas ocasiões, pode ser a força motriz dos oprimidos, a voz dos subjugados, a bandeira das lutas sociais. Contudo, para que isso ocorra, é necessária uma articulação muito específica entre os diversos elementos sociais, que favoreça a criação de uma religião contestadora da ordem vigente. São essas condições materiais que Engels busca investigar.

Seguindo as diversas reflexões de Engels sobre a dimensão religiosa, esta pesquisa tem por objetivo identificar e analisar como este pensador e militante trata sociologicamente a questão da articulação orgânica entre o fenômeno religioso e a política no 
contexto de luta de classes nas rebeliões camponesas que se desenrolaram na Alemanha em 1524-1525.

Nesta pesquisa, além de debruçarmo-nos sobre as obras do próprio Engels ${ }^{5}$, recorreremos a textos de seus comentadores, bem como de autores que se propõem a estudar a sociologia marxista da religião, como, por exemplo, Michael Löwy, Elizete da Silva, entre outros. Este trabalho conta com a colaboração de dois pesquisadores, a saber: Michael Löwy ${ }^{6}$ e Lívia Cotrim (in memoriam) ${ }^{7}$, que participaram concedendo, gentilmente, uma entrevista, de acordo com a especialidade de cada um. Suas contribuições forneceram instrumentos analíticos para compreender a complexidade do sistema de pensamento de Engels (seus métodos, conceitos e categorias), a partir de diferentes perspectivas.

\section{AS CIRCUNSTÂNCIAS MATERIAIS DOS CONFLITOS SOCIORRELIGIOSOS}

No prefácio à segunda edição da obra As Guerras Camponesas na Alemanha, Engels faz um paralelo entre as revoluções de 1848-1850 e de 1524-1525, mas, "apesar de tantas analogias, ambas as revoluções, a do século 16 e a de 1848-1850, diferenciam-se profundamente" (ENGELS, 2010 [1850]: 158). Uma das grandes diferenças é que a revolução de 1525 se desenvolveu especificamente na Alemanha, enquanto que a de 1848-1850 teve um contexto mais amplo, envolvendo o continente europeu como um todo. A análise sociológica sobre o movimento do século XIX fornece elementos para compreender as guerras camponesas de 1524-1525 e vice e versa.

Os esforços de Engels, ao refletir sobre essas duas experiências revolucionárias, têm por objetivo produzir um conhecimento prático político. Mauro lasi afirma que, "todo o pano de fundo do trabalho de Engels é a paciente afirmação sobre a necessidade de os trabalhadores se apresentarem como força revolucionária autônoma, para não se diluírem nos caminhos da revolução burguesa" (2010: 16).

Sobre as insurreições camponesas na Alemanha, Engels elucida que o principal material utilizado para produzir suas reflexões são os estudos de Wilhelm Zimmermann:
5 Para situar melhor o leitor em relação às citações diretas de Engels, o ano original de lançamento ou de escrita da obra virá em colchete logo após o ano da edição, por exemplo: (ENGELS, 2010 [1850]).

6 Diretor emérito de pesquisas do Centre National de la Recherche Scientifique (CNRS).

7 Lívia Cotrim, pouco
tempo depois de
colaborar com esta
pesquisa, faleceu no dia
14 de agosto de 2019. Era
professora do Centro
Universitário Fundação
Santo André (FSA).


A obra não pretende fornecer um material novo, fruto das minhas próprias investigações. Ao contrário, todo o material que se refere às insurreições camponesas e a Thomas Münzer foi recolhido em Zimmermann. Apesar das lacunas, o livro desse autor constitui a melhor compilação de dados aparecida até esta data. (ENGELS, 2010 [1850]: 39)

Vale à pena mencionar que este artigo não discutirá a qualidade científica dos resultados históricos obtidos por Engels, o que mais nos interessa é compreender como este pensa, sociologicamente, a questão do fenômeno religioso, que de acordo com Michael Löwy, são reflexões inovadoras, pois Engels teria criado "um novo modo de análise da religião, com base no estudo das ligações entre as mudanças econômicas, conflitos de classe e transformações religiosas" (1997: 39).

No primeiro capítulo, a narrativa de Engels se inicia com "uma análise da situação econômica e da estrutura social da Alemanha" (SILVA, 2007: 176), que no século XVI já atravessa um período de mudanças; uma parte do norte alemão já havia se emancipado do sistema feudal, "graças ao monopólio secular da navegação exercido pela Liga hanseática" (ENGELS, 2010[1850]: 57). As inovações da tecnologia militar colocavam em xeque os antigos dispositivos de proteção do sistema econômico feudal, pois "a importância crescente da infantaria, o aperfeiçoamento das armas de fogo aniquilaram o seu poder guerreiro reduzindo a eficácia da cavalaria pesada e acabando com a fortaleza inexpugnável dos seus castelos" (ENGELS, 2010 [1850]: 61).

A pequena nobreza estava paulatinamente empobrecendo e 0 aumento nas cobranças de tributos e da servidão não Ihes retirava da situação econômica que estavam experimentando, além disso, cresciam as divergências com os príncipes. De modo simplificado, a pequena nobreza passa a olhar com interesse o cabedal da Igreja Católica. "O clero, sobrecarregado de riquezas, parecia aos cavaleiros uma classe inútil; cobiçavam a sua enorme quantidade de bens, os seus tesouros acumulados graças ao celibato, e à constituição eclesiástica" (Ibidem). A Igreja Romana, representante ideológica do feudalismo medieval, também estava sendo golpeada pelas transformações históricas. Mesmo recebendo o dízimo, os direitos feudais e a cobrança

8 A Liga hanseática era uma "federação de cidades do norte da Alemanha, formada para proteger interesses comerciais mútuos" (LOYN, Zahar, 1997: 445). 
de outros impostos, o clero católico lançou mão de outra atividade que the garantia novos rendimentos: o "fabrico de imagens e relíquias milagrosas, à comercialização das peregrinações, à venda de bulas, o que conseguiram com bastante êxito durante algum tempo" (Op. cit: 62).

Os servos tinham uma vida de carência material. Na maior parte do tempo, trabalhavam nas terras do senhor, e quando trabalhavam em suas próprias terras, eram obrigados a pagar o dízimo, e uma série de outros impostos, "não se podia casar nem morrer sem pagar alguma coisa ao seu senhor" (Op. cit: 68). Inclusive, o senhor tinha o direito de pernada, "que concedia aos nobres a noite de núpcias de suas servas" (/bidem).

Apesar de existência sofrida e humilhante, dificilmente os servos se rebelavam contra aquela estrutura tirânica. Para Engels, a subjetividade intrageracional, o padrão de sociabilidade, os fatores culturais e as diferentes dinâmicas de exploração de cada propriedade feudal desestimulavam a formação de movimentos insurretos. Para Engels, "o costume secular da submissão, transmitido de geração em geração, e em muitas regiões a perda do hábito de usar armas, a dureza maior ou menor da exploração que variava de acordo com a pessoa do senhor contribuíram para mantê-los imobilizados" (2010 [1850]: 68-69). Os movimentos camponeses contestadores durante a Idade Média eram localmente situados e "antes da guerra camponesa não se verificou nenhuma insurreição geral de todos os camponeses" (Op. cit: 69).

Diante desse quadro, as reformas protestantes fizeram surgir dois grandes grupos (que não eram os únicos) de oposição à Igreja e às instituições feudais: os luteranos, que eram moderados e reformadores, representavam a burguesia e a pequena nobreza; e os anabatistas, liderados por Thomas Münzer, que eram uma vertente revolucionária que representava os interesses dos camponeses, plebeus e do nascente proletariado. No início das reformas, ambos se uniram para combater a Igreja Católica, que constituía o campo reacionário e representava os interesses do alto clero, o patriciado das cidades, o império e a alta nobreza. Apesar da participação intensa de diversas correntes religiosas nos conturbados eventos no início do 
século XVI, Engels afirma que não se tratava de uma guerra religiosa, e sim de "interesses materiais e de classe muito positivos e essas guerras foram lutas de classe" (ENGELS: 2010 [1850]: 72).

Para compreender a dimensão religiosa das guerras camponesas é de extrema relevância considerar a importância que a Igreja Católica exercia não só na Alemanha, mas em toda a Europa ocidental. Para a historiadora Lívia Cotrim, "na Idade Média, a Igreja Católica (...) estava ligada à conservação do feudalismo, portanto, ao interesse das classes que nele dominavam. Nesse sentido, buscou resistir de diferentes maneiras ao avanço do capitalismo, seja em termos de organização produtiva, seja em termos do desenvolvimento científico e artístico" (COTRIM, 2019, entrevista concedida a esta pesquisa).

Essa instituição "era o grande centro internacional do feudalismo (...) [e] unia toda a Europa ocidental feudalizada" (ENGELS, 1999 [1880]: 30). Sua teologia penetrava todos os ramos da atividade intelectual, "o dogma da Igreja era simultaneamente axioma político e os textos sagrados tinham força de lei em todos os tribunais" (2010 [1850]: 73). Mesmo com a criação do ofício independente dos juristas, a Igreja permaneceu influenciando, vigorando como potência jurídica.

A Igreja Católica, na Idade Média, exercia influência sobre a maioria das instituições feudais, e se estruturou hierarquicamente "segundo o modelo feudal e era, afinal de contas, o maior de todos os senhores feudais, pois possuía pelo menos a terça parte de toda a propriedade territorial do mundo católico" (ENGELS, 1999 [1880]: 30). Era uma potência religiosa, econômica, política, jurídica, militar, educacional, científica, artística e filosófica. Neste sentido, "todas as doutrinas revolucionárias sociais e políticas deviam constituir em primeiro lugar heresias teológicas" (ENGELS, 2010 [1850]: 73).

No final do século XV e início do XVI, na Alemanha, a linguagem teológica era a força catalisadora dos descontentamentos das classes sociais. Como já dito, a Igreja Católica era a maior instituição da Europa ocidental, seu poder transcendia a própria dimensão religiosa e alcançava outras esferas da existência humana. Todo esse poderio, em parte, se explica pelo fato da Igreja ter se tornado uma "herdeira natural" do Império Romano, por reformular suas instituições e por se 
estruturar numa rígida hierarquia, pela concentração de propriedades e pelo celibato clerical que impedia a divisão de seu patrimônio (FRANCO JUNIOR, 2001).

A Igreja Católica não permitia a livre interpretação dos textos bíblicos, e um dos mecanismos de controle adotado era a proibição da tradução da Bíblia. Os "textos sagrados" tinham de ser escritos e lidos exclusivamente em latim (herança do Império Romano). Essas e outras práticas permitiram ao corpo eclesiástico da igreja romana instituir um conjunto de normas e valores que se tornaram dominantes ao longo dos séculos no período medieval. Ela não detia apenas os meios materiais de sua dominação, mas também produzia as ideias dessa dominação e administrava a distribuição dessas ideias na sociedade ${ }^{9}$. Engels e Marx, na obra $A$ Ideologia Alemã, postularam que "as ideias da classe dominante são, em cada época, as ideias dominantes, isto é, a classe que é a força material dominante da sociedade é, ao mesmo tempo, sua força espiritual dominante" (ENGELS; MARX, 2007 [1846]: 47).

Para preservar a unidade da Igreja, sua hegemonia e combater as heresias, organizavam-se concílios e sínodos. De acordo com Franco Junior, a "heresia era (...) um desvio dogmático que colocava em perigo a unidade de fé" (2001: 91). Aqueles que ousavam desafiar as regras estabelecidas pela doutrina católica sentiam o peso dessa instituição, que acionava uma série de mecanismos punitivos, que poderiam resultar, em excomunhão, torturas físicas e até mesmo em subtração da vida. Todavia, todas as ações eram justificadas teologicamente, para Engels, "essa supremacia da teologia em todos os ramos da atividade intelectual era devida também à posição singular da Igreja como símbolo e sanção da ordem feudal" (2010 [1850]: 73).

Foi dentro desse contexto que a subversão doutrinária e teológica de Martinho Lutero contra a "Igreja Católica dera impulso aos elementos mais descontentes" (WILSON, 1987: 195). Entretanto, por mais que a ação do monge agostinho da Turíngia fosse de natureza doutrinária, ela foi captada politicamente pelos diversos setores insatisfeitos daquele período na Alemanha.

Engels percebe que as heresias se diferenciavam entre si conforme a classe social, os camponeses em geral apresentavam
9 Engels em $A$ Situação da Classe Trabalhadora na Inglaterra (2010[1844/45]) denomina de "maquinaria religiosa" a infraestrutura criada e utilizada pela igreja para a difusão de suas ideias. 
propostas mais radicais que ameaçavam a hegemonia da Igreja Católica e do mundo feudal. Muitos movimentos exigiam "a restauração da igualdade cristã entre os membros da comunidade e o seu reconhecimento como norma para a sociedade inteira. A igualdade dos filhos de Deus deveria traduzir-se pela igualdade dos cidadãos e até pela dos seus bens" (ENGELS, 2010 [1850]: 75). Alguns movimentos representam muito bem essa tendência, como os albigenses (cátaros), os taboritas e os anabatistas.

Os anabatistas durante a reforma protestante foram aos poucos se aglutinando em torno da liderança do pastor protestante, Thomas Münzer. Este teólogo revolucionário idealizou um tipo de sociedade que Engels chegou a definir como "esboço de comunismo", e suas concepções expressavam "as ânsias de toda uma fração da sociedade" (2010 [1850]: 76). Foi justamente sob a liderança de Münzer que plebeus e camponeses formaram um partido com um programa revolucionário.

Martinho Lutero, por sua vez, teve uma postura de desaprovação dos movimentos camponeses e plebeus, e afirmava que não era ele que condenava, mas sim o próprio Deus. Apesar dessa oposição entre Lutero e os camponeses sublevados, Engels afirma que Lutero involuntariamente teria contribuído para o surgimento de novas interpretações bíblicas ao traduzir a Bíblia do latim para o alemão. Isto acabou se tornando um material inflamável nas mãos dos movimentos insurgentes, uma vez que estes passaram a conhecer um cristianismo diferente do que era praticado pela Igreja Católica. "Na Bíblia tinha oposto do cristianismo simples dos primeiros séculos ao cristianismo feudal da época" (ENGELS, 2010 [1850]: 81).

No sentido dialético, a mesma Bíblia que serviu de instrumento de dominação, de justificativa das desigualdades sociais, para amansar os espíritos no sentido de convencer os servos a entregar de bom grado a "césar o que é de césar e a Deus o que é de Deus"10, agora, nas mãos dos insurgentes, ganhava novas interpretações. "Esse instrumento fora empregado a fundo pelos camponeses contra os

${ }^{10}$ Bíblia Sagrada, Mateus, cap. 22, vers. 21. 
iniciou e tudo isso em benefício dos príncipes que o apoiavam. Engels define o papel que Lutero e Münzer ocupavam naquele contexto da seguinte maneira: "Lutero, reformador burguês, oponhamos a Münzer, revolucionário plebeu" (Ibidem) - exatamente por seu caráter revolucionário que Engels demonstrava abertamente uma simpatia política por este último.

Münzer é, para Engels, um agitador, que, em seus discursos, incentivava a luta armada; o conteúdo de seus argumentos era teológico e se voltava contra aqueles que consideravam inimigos de Deus, do evangelho e do povo. Engels identificava as elaborações teológicas de Münzer como inovadoras: "sob as formas cristãs, Münzer ensinava um panteísmo que tem uma estranha semelhança com as teorias especulativas modernas, avizinhando-se por vezes do ateísmo. Desprezava a Bíblia como revelação única" (Op. cit:: 82).

Thomas Münzer era um pregador protestante fervoroso, "que propunha o imediato estabelecimento do Reino de Deus na terra" (ENGELS, 2010 [1850]: 83), sua linguagem, seu modo de pensar e agir era fundamentado por valores teológicos. Este "profeta da revolução", na assinatura de suas epístolas se auto intitulava "servo de Deus", "servo de Deus, contra os ímpios", ou então, assinava "Tomas Münzer, com a espada de Gideão"11. Seus discursos e textos eram repletos de referências a personalidades bíblicas e cada frase proferida era fundamentada nos textos do "livro sagrado". Suas pregações eram, ao mesmo tempo, de natureza religiosa e política.

Na concepção de Münzer, "os príncipes e grandes senhores são a escória dedicada à usura, ao roubo e ao banditismo; apropiam-se de toda a criação; pertencem-Ihes os peixes na água, as aves no ar e as plantas na terra. E, além disso, pregam aos pobres: "não roubarás'" (ENGELS, 2010 [1850]: 84). Essa situação que, inevitavelmente, massacrava as classes subalternas era inadmissível, somente o "estabelecimento imediato do reino de Deus, da era milenar de felicidade" (Op. cit:: 83) poderia inverter esse quadro. O reino de Deus na terra significava para Münzer "uma sociedade sem diferenças de classe, sem propriedade privada e sem poder estatal independente e estranho aos membros da sociedade" (Ibidem).
11 MÜNZER, Thomas. Cartas de Thomas Müntzer. In: YODER, John Howard. Textos escogidos de la Reforma radical. Barcelona: Biblioteca Menno, 2016. 
As posições políticas de Thomas Münzer sobre como a sociedade deveria se organizar inspirava-se teologicamente em uma determinada passagem do livro de Atos dos Apóstolos, que dizia: "todos os que tinham abraçado a fé reuniram-se e punham tudo em comum; vendiam suas propriedades e bens, e dividiam-nos entre todos, segundo as necessidades de cada um" (2002: 1905, cap. 2, ver. 44-45).

Thomas Münzer era extremamente ativo politicamente, fazia pregações, escrevia panfletos, enviava mensageiros para as diversas regiões da Alemanha e organizava pessoalmente a liga secreta de Alstedt. Denunciava a opressão dos príncipes, incentivava a morte de frades e a destruição de capelas, como a de Santa Maria em Mallerbach, próximo a Alstedt. As ideias de Münzer se difundiam na medida em que aumentava a agitação entre plebeus e camponeses, até encontrar "agentes inestimáveis na pessoa dos anabatistas" (ENGELS, 2010 [1850]: 86). De acordo com Engels, essa seita se caracterizava por não ter

\footnotetext{
um dogma positivo bem definido [e que] estava aglutinada pela oposição de todas as classes dominantes e pelo símbolo comum do segundo batismo, [além] disso, tinham uma vida severa e ascética; incansáveis, fanáticos e impávidos na agitação, tinham-se agrupado cada vez em redor de Münzer. (2010 [1850]: 86-87)
}

O reino de Deus da era milenar na terra, de acordo com Engels, não se tratava de uma ideia abstrata que estava distanciada da realidade, mas, pelo contrário, Münzer e os anabatistas tinham estratégias de ações muito bem definidas para alcançar seus objetivos, em síntese: matar os governantes ímpios; queimar castelos; descentralizar o dízimo; confiscar os bens eclesiásticos; todos os cidadãos deveriam trabalhar; acabar com os impostos etc. Essas eram propostas de ações práticas para o estabelecimento do reino de Deus na terra, se tratavam de ações que almejavam atingir as classes sociais e a propriedade privada, para, dessa forma, emancipar toda a humanidade.

Essa proposta era diferente do comunismo praticado e estimulado pelas primeiras comunidades cristãs no século I da Era Comum. Os primeiros cristãos incentivaram aqueles que tinham 
propriedades a vendê-las e compartilhar o dinheiro obtido, distribuindo conforme a necessidade de cada um, e assim se promovia a igualdade entre os membros, de modo que ninguém teria mais recursos materiais acumulados do que o outro. Aqueles que guardassem uma parte do dinheiro para si seriam severamente punidos, isso pode ser verificado no caso de Ananias e sua esposa Safira em Atos dos Apóstolos:

Disse Ihe então Pedro: "Ananias, por que encheu Satanás o
teu coração para mentires ao Espírito Santo, retendo parte
do preço do terreno?" (...) Ao ouvir estas palavras, Ananias
caiu e expirou (...). Passou-se o intervalo de cerca de três
horas. Sua esposa, nada sabendo do que sucedera, entrou.
Pedro interpelou-a: "Dize-me, foi por tal preço que
vendestes o terreno?" E ela respondeu "Sim, por tal preço"
(...) No mesmo instante ela caiu a seus pés e expirou.
(2002, 1908-9, cap. 05, vers. 03, 05, 07, 08 e 10)

Todavia, como bem observa Rosa Luxemburgo (1980), o comunismo dos primeiros cristãos estava fadado a durar pouco tempo, pois não se atingia a propriedade privada; o convertido, ao vender seus bens, estava apenas transferindo a propriedade para outrem através de uma transação comercial. Além disso, os recursos advindos da venda do imóvel tinham pouca durabilidade. "Após um pequeno lapso de tempo, as pessoas, tendo consumido as riquezas distribuídas, teriam uma vez mais as mãos vazias" (LUXEMBURGO, 1980: 32). O que está sendo socializado nessa experiência sociorreligiosa não é a propriedade e sim os elementos derivados dela, como dinheiro (a partir de operações comerciais) e produtos acabados.

Na obra Anti-Duhring, Engels afirma que a igualdade promovida pelas primeiras comunidades cristãs era limitada, uma vez que "os vestígios da comunidade dos bens (...) nos primeiros tempos da nova religião, tinham a sua origem mais na solidariedade entre os perseguidos do que numa verdadeira ideia de igualdade" (ENGELS, 1990 [1878]: 87). A verdadeira "igualdade entre os homens" estaria na concepção teológica de "pecado original, igualdade essa que se enquadrava perfeitamente no seu caráter de religião dos escravos e dos oprimidos" (/bidem). 
As propostas de Münzer e dos anabatistas ultrapassavam a do cristianismo primitivo, uma vez que difundiam a perspectiva da coletivização da propriedade, uma sociedade onde "tudo é de todos" (omnia sunt communia), porém as condições materiais existentes não eram favoráveis à sua realização - é o que vamos discutir na próxima seção.

\section{EXPECTATIVAS VERSUS POSSIBILIDADES DE REALIZAÇÃO}

No sudoeste da Alemanha, Münzer se torna o "eixo de todo o movimento revolucionário". Por meio de sua figura, se estabeleceu uma conexão entre as diversas regiões da Alemanha, inúmeras lideranças reconhecidas se tornaram seus signatários. Engels Ihe atribui uma postura totalmente revolucionária, embora as condições materiais ainda não estivessem asseguradas para a implementação de um tipo de sociedade que este ator social idealizava.

Münzer "representava uma classe que se encontrava totalmente à margem da sociedade oficial, isto é, os germes do proletariado, pressentiu o comunismo" (ENGELS, 2010 [1850]: 130). Münzer produziu uma visão de mundo que estava associado à posição virtual que este ocupava na sociedade e seu histórico de relações. Engels afirma que, "na história da sociedade, os agentes são todos homens dotados de consciência, que atuam sob o impulso da reflexão ou da paixão, buscando determinados fins; aqui nada se produz sem a intenção consciente, sem um fim desejado" (ENGELS, 1963 [1886]: 198). Isso não significa alcançar aquilo que foi planejado e sim a capacidade de atuar conscientemente no sentido de "colocar-se determinadas metas e empenhar-se em alcançá-las" (KOFLER, 2010: 112).

As forças motrizes identificadas por Engels que justificava a concepção de uma nova sociedade para o teólogo da revolução era a decomposição da estrutura feudal. As profundas mudanças no sistema social favoreceram a produção de novas concepções de sociedade no porvir, ainda que algumas delas não estivessem em plenas condições de ser implementadas, mas a idealização fazia parte de um movimento real, que estava abolindo o estado de coisas presentes. Em outras palavras, eram "o resultado, um pouco idealizado, mas necessário, da 
dissolução em que se encontrava a sociedade feudal" (ENGELS, 2010 [1850]: 130).

Esse momento histórico favoreceu a pulverização de novas ideias de organização da sociedade, Thomas Münzer, exatamente nesse contexto, idealizou algo que ainda não era possível de se realizar, uma sociedade sem classes sociais. Concebeu também uma nova religião, totalmente diferente do modelo da Igreja Católica e dos reformadores luteranos, uma religião que seria mais próxima dos membros da comunidade. Para isso, Münzer pregava que era preciso eliminar a riqueza da igreja e descentralizar o dízimo, um dos objetivos dessas e outras ações era resgatar a igreja primitiva.

Por mais que as reivindicações camponesas fossem avançadas, elas paulatinamente se flexibilizaram no sentido de favorecer as pautas burguesas, "tiveram de se subordinar aos interesses definitivos dos burgueses e não às reivindicações momentâneas destes" (ENGELS, 2010 [1850]: 130). Por isso, Engels afirma que, por mais que Münzer representasse os camponeses, plebeus e os germes do proletariado, acabava tomando atitudes que convergiam com os interesses de uma classe que ele não representava. Por exemplo, a luta empreendida por Münzer pela unificação de moedas, pesos e medidas na cidade Alsted. Para Engels, "formularam-se reivindicações de acordo com os interesses da burguesia das cidades, muito mais do que no interesse dos camponeses" (/bidem).

Neste sentido, o sujeito "vê se forçado a representar, não o seu partido ou sua classe, mas sim a classe chamada a dominar nesse momento" (Op. cit: 142). No movimento da matéria, dada às condições materiais existentes, "o interesse do próprio movimento obriga-o a servir uma classe que não é a sua e a entreter a sua própria classe com palavras, promessas e com a afirmação de que os interesses daquela classe alheia são os da sua" (Ibidem).

Por mais que este líder revolucionário e sua perspectiva religiosa e política fosse uma expressividade do contexto sociohistórico, a "alteração da estrutura social que tinha imaginado não tinha qualquer fundamento nas circunstâncias materiais existentes" (Op. cit:: 143). Engels argumenta que, por mais que a classe social dos camponeses, plebeus e proletários fosse avançada em suas propostas e ações 
práticas, sua autonomia era limitada em relação às outras classes sociais, pois as "circunstâncias materiais existentes" não permitiam que suas ações fossem dotadas de radicalidade como desejavam. Por mais que Münzer tivesse paixão revolucionária e o fervor religioso dos profetas do Antigo Testamento, a "classe que representava acabava de nascer e não estava ${ }^{12}$, de modo algum, completamente formada nem podia subjugar e transformar toda a sociedade" (/bidem).

Outros aspectos também foram materialmente decisivos para inviabilizar a realização das pautas idealizadas por Münzer, como o isolamento, a carência de diálogo, comunicação e solidariedade entre os diversos movimentos e comunidades. Isso contribuiu para a falta de unidade política, teórica e prática entre eles. "Em cada província os camponeses atuavam por sua própria conta negando-se a ajudarem os seus vizinhos e como desse modo foram aniquilados isoladamente em sucessivas batalhas e por exércitos que nem sequer somavam a décima parte da totalidade dos insurgentes" (2010[1850]: 157). Há de se considerar também outros fatores, como os equívocos estratégicos, a falta de organização e disciplina, o desânimo, a deserção, o despreparo para o combate, a falta de material bélico adequado, deficiência logística etc.

Engels verifica dialeticamente as contradições internas dos fenomenos sociais e enxerga um grande distanciamento entre expectativas e possibilidade de realização. É neste sentido que Harnecker afirma que uma das grandes contribuições de Engels e Marx "é haverem eles descoberto que para estudar a sociedade não se deve partir do que os homens dizem, imaginam ou pensam, mas da forma em que produzem os bens materiais necessários à sua vida" (HARNECKER, 1981: 92).

De acordo com Michael Löwy (2015), Engels compreende que a concepção religiosa de Münzer não é um reflexo passivo da realidade, pelo contrário, a religiosidade do teólogo radical antecipava uma nova sociedade. É neste sentido que a doutrina política de Münzer "deriva diretamente do seu pensamento religioso revolucionário e antecipavase à situação social e política da sua época, tal como a sua teologia se antecipava às ideias e conceitos correntes" (ENGELS, 2010 [1850]: 83). 12 Aqui, Engels se refere
especificamente ao
proletariado. 
A teologia revolucionária de Thomas Münzer o colocou como um "precursor do comunismo" que aspirava uma sociedade do "reino milenário de igualdade social republicana" (Op. cit: 84). Sobre esse tema, Löwy afirma que "estamos aqui nos antípodas da teoria da 'reflexão': longe de ser a simples 'expressão' das condições existentes, a doutrina político-religiosa de Münzer apareceu como uma 'antecipação genial' das aspirações comunistas do futuro" (LÖWY, 1997: 34). Para Engels, as concepções de Thomas Münzer eram tão avançadas "que muitas seitas comunistas modernas em véspera da revolução de fevereiro [1848] não dispunham de um arsenal teórico tão rico como 'os de Münzer' no século 16" (ENGELS, 2010 [1850]: 83).

Para Engels, o cristianismo revolucionário münzeriano não é fonte de alienação e nem de enganação, pelo contrário, ela devolve a humanidade e fornece elementos para compreender as mazelas provocadas pelas estruturas sociais, se tornando, dessa forma, uma teologia a serviço da transformação social.

\footnotetext{
O que Engels propõe é algo novo: não mais uma discussão sobre a religião como "alienação da natureza humana" (Feuerbach e os neo-hegelianos de esquerda), ou como conspiração clerical para enganar o povo (a filosofia das Luzes). O que lhe interessa é a religião como fenômeno social e histórico, inserido no campo da luta de classes (LÖWY, 2019, entrevista concedida a esta pesquisa).
}

A partir das reflexões sociológicas e históricas de Engels, Ernst Bloch desenvolve, posteriormente, toda uma reflexão sobre a dimensão antecipadora da religião em Münzer. John Rex afirma que Ernst Bloch, "em seu livro sobre Thomas Münzer (1921), [...] vê a revolução anabatista do século XVI como uma pré-figuração daquilo que só em 1917 seria plenamente realizado com a revolução bolchevique" (REX, 2012: 63).

\section{CONSIDERAÇÕES FINAIS}

A obra, As guerras camponesas na Alemanha, não traz análises sobre os elementos litúrgicos, simbólicos ou mitológicos do fenômeno religioso. Apenas de modo superficial Engels trata de alguns desses aspectos. O que se encontra é exatamente um olhar atento sobre o papel desempenhado pela religião no contexto de luta de classes na 
Alemanha no início do século XVI. Os aspectos teológicos são abordados na medida em que ajudam o autor a entender as especificidades políticas de cada força religiosa e quais as classes sociais vinculadas a cada uma delas por afinidade de sentido.

Três grandes forças religiosas são identificadas pelo socialista alemão: a Igreja Católica, que tinha uma posição reacionária; os luteranos, que se colocavam como moderados; e os anabatistas, que eram revolucionários. Ao longo deste trabalho, optamos por privilegiar este último, uma vez que é muito comum encontrar entre os adeptos do marxismo ideias que compreende o fenômeno religioso sendo intrinsecamente constituído por um conjunto de características, como a de ópio do povo ${ }^{13}$, fonte de alienação e de enganação, reflexo da estrutura socioeconômica, conservadorismo e reacionarismo ${ }^{14}$.

As análises de Engels acerca da atuação de Thomas Münzer e os anabatistas nas rebeliões camponesas não comportam nenhum desses pressupostos. Suas conclusões se contrapõem a essas interpretações, pois, na sua concepção, a religião não possui nenhuma essência em si, trata-se de um fenômeno histórico social, uma forma cultural em constante movimento que se transforma ininterruptamente, compondo e se decompondo incessantemente ao longo da história e assumindo variadas formas. Sua configuração está relacionada diretamente a seu histórico de interações e de uma combinação muito precisa entre diversos elementos sociais.

Abordamos a base material (os aspectos políticos, econômicos e religiosos) apontada por Engels que culminou nas guerras camponesas. $\mathrm{O}$ autor indica que a dissolução da sociedade feudal e a posição da Igreja Romana nesse sistema social foram cruciais não só para produzir esses conflitos, mas também para lhes caracterizar como sociorreligiosos. Apesar dos conflitos serem permeados por uma linguagem religiosa, Engels afirma que não era a dimensão religiosa que os engendra, e sim os fatores políticos e econômicos. No entanto, o fator religioso é extremamente importante e não é possível compreender esse período ignorando-o.

Pelas "condições materiais existentes", Engels analisa quais eram as possibilidades de realização das propostas de cada força religiosa e classe social. No caso de Münzer e dos anabatistas, que representavam
13 Michael Löwy chama atenção para o fato de que geralmente cita-se esta "frase de forma truncada: Marx fala da religião como 'suspiro da criatura oprimida', e como sendo, ao mesmo tempo, expressão da miséria real e protesto contra ela" (LÖWY, 2019, entrevista concedida a esta pesquisa). "A miséria religiosa constitui ao mesmo tempo a expressão da miséria real e o protesto contra a miséria real. A religião é o suspiro da criatura oprimida, o ânimo de um mundo sem coração, assim como o espírito de estados de coisas embrutecidos. Ela é o ópio do povo" (MARX, 2010 [1843/1844]: 145).

14 Uma parte dessas concepções deriva de uma leitura parcial da Introdução à Crítica à Filosofia do Direito de Hegel, de Marx, de $1843 / 1844$. 
os plebeus, os camponeses e os germes do proletariado, as propostas para a produção de novos deveres societários eram avançadas, mas a base material não oferecia suporte para sua realização. Dentro daquelas circunstâncias, era mais favorável a realização das pautas da classe burguesa.

Engels se esforça por produzir uma análise completa que abrange as "múltiplas determinações" do objeto investigado, considerando os aspectos estruturais, conjunturais, situacionais, geográficos, micro e macro sociais. É com essas características que procura destrinchar analiticamente a relação entre religião e política na luta de classes que se desenvolveu na Alemanha na segunda década do século XVI.

\section{REFERÊNCIAS BIBLIOGRÁFICAS}

BÍBLIA de Jerusalém. Tradução de Ivo Storniolo, Euclides Martins Balancin, Jorge Cesar Mota et.al. São Paulo: Paulus, 2002, reimpressão 2019.

COTRIM, Lívia. Entrevista concedida a esta pesquisa em 04 de julho de 2019.

ENGELS, Friedrich. As Guerras camponesas na Alemanha. A revolução antes da revolução. São Paulo: Expressão Popular, 2010[1850].

ENGELS, Friedrich. Do Socialismo Utópico ao Socialismo Científico (versão digital). Ridendo Castigat Mores, 1999 [1880].

ENGELS, Friedrich; MARX, Karl. A Ideologia Alemã. São Paulo: Boitempo, 2007 [1846].

ENGELS, Friedrich. Ludwig Feuerbach e o fim da filosofia clássica alemã. Obras escolhidas. Vol. 03. Rio de Janeiro: Editorial Vitória, 1963 [1886], pp.171-207.

ENGELS, Friedrich. Anti-Dühring. São Paulo: Paz e Terra, 1990 [1878].

FRANCO JUNIOR, Hilário. A Idade Média: nascimento do ocidente. São Paulo: Brasiliense, 2001.

HARNECKER, Marta. Os Conceitos Elementares do Materialismo Histórico. São Paulo: Global, 1981. 
IASI, Mauro. Introdução. In: ENGELS, Friedrich. A revolução antes da revolução. São Paulo: Expressão Popular, 2010, pp.07-34.

KOFLER, Leo. História e Dialética. Rio de Janeiro: Editora UFRJ, 2010.

LÖWY, Michael. Engels como sociólogo da Religião (Curso/aula 02), $2015 . \quad$ Disponível em: <https://www.youtube.com/watch?v=cXzd57sYOg4>.

LÖWY, Michael. Entrevista concedida a esta pesquisa em 29 de abril de 2019.

LÖWY, Michael. Friedrich Engels et la religion. In: LABICA, Georges; DELBRACCIO, Mireille. Friedrich Engels, Savant et Revolutionnaire. Paris: Puf, 1997, pp. 29-39.

LOYN, Henry R. Dicionário da Idade Média. Rio de Janeiro: Zahar, 1997. Disponível em: <https://professordiegodelpasso.files.wordpress.com/2016/05/h-rloyon-dicionc3a1rio-da-idade-mc3a9dia.pdf $>$.

LUXEMBURGO, Rosa. O Socialismo e as Igrejas. O Comunismo dos Primeiros Cristãos. Rio de Janeiro: Achiamé, 1980.

MARX, Karl. Crítica à Filosofia do Direito de Hegel. São Paulo: Boitempo, $2010[1843 / 1844]$.

NETO, João Oliveira Ramos. Fé Subversiva: Uma análise do conflito sociopolítico da ideologia anabatista com as demais propostas da Reforma Protestante na Europa Central entre os anos de 1525 a 1555. Tese de Doutorado. 2016. Universidade Federal de Goiás, Programa de Pós-Graduação em História. Disponível em: <https://repositorio.bc.ufg.br/tede/bitstream/tede/6054/5/Tese\%20\%20J.\%C3\%A30\%200liveira\%20Ramos\%20Neto\%20-\%202016.pdf>.

REX, John. Bloch, Ernest (verbete). In: BOTTOMORE, Tom. Dicionário do Pensamento Marxista. Rio de Janeiro: Zahar, 2012, pp. 62-63.

SILVA, Elizete da. Engels e a abordagem científica da religião. In: MOURA, Mauro Castelo Branco de et al (orgs.). Friedrich Engels e a ciência contemporânea. Salvador: EDUFBA, 2007, pp. 171-188.

WILSON, Edmund. Rumo à Estação Finlândia. São Paulo: Companhia das 